$$
\text { DOEJPC/ } 95154 \text { - TI }
$$

TECHNICAL PROGRESS REPORT

\title{
PRECOMBUSTION REMOVAL OF HAZARDOUS AIR POLLUTANT PRECURSORS
}

Contract No.: DE-AC22-95PC95154

Technical Project Report for the First Quarter

October 1, 1995 - December 31, 1995

\section{Prime Contractor:}

Department of Mining and Minerals Engineering Virginia Polytechnic Institute and State University Blacksburg, Virginia 24061-0239

\section{Subcontractors:}

Clark-Atlanta University

Southern Illinois University at Carbondale

Electric Power Research Institute

Consol Inc.

Prepared for:

Pittsburgh Energy Technology Center

U.S. Department of Energy

P.O. Box 10940

Pittsburgh, Pennsylvania 15236

Contracting Officer's Representative: Richard Read

Date Submitted: January 19, 1996

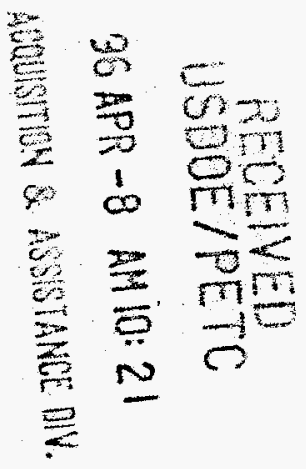




\section{DISCLAIMER}

Portions of this document may be illegible in electronic image products. Images are produced from the best available original document. 


\section{DISCLAIMER}

This report was prepared as an account of work sponsored by an agency of the United States Government. Neither the United States Government nor any agency thereof, nor any of their employees, make any warranty, express or implied, or assumes any legal liabiity or responsibility for the accuracy, completeness, or usefulness of any information, apparatus, product, or process disclosed, or represents that its use would not infringe privately owned rights. Reference herein to any specific commercial product, process, or service by trade name, trademark, manufacturer, or otherwise does not necessarily constitute or imply its endorsement, recommendation, or favoring by the United States Government or any agency thereof. The views and opinions of authors expressed herein do not necessarily state or reflect those of the United States Government or any agency thereof. 


\begin{abstract}
This project involves the development of an optimized, bench-scale processing circuit capable of efficiently removing trace elements from run-of-mine coals. The optimized circuit will be developed using characterization data obtained from detailed washability studies and release analyses tests conducted with several eastern U.S. coals. The optimized circuit will incorporate a variety of conventional and advanced coal cleaning processes which are believed to be the most cost-effective and commercially viable. The coal products from the optimized circuit will be further treated with complexing agents specifically designed to extract organometallic trace elements that are difficult to remove by physical cleaning operations. Finally, innovative bioremediation schemes will be investigated as a means of controlling the release of trace elements from the process waste streams. Emphasis has been placed on the development of a processing circuit which (i) maximizes the rejection of trace elements, (ii) minimizes the production of coal fines which are costly to process and less marketable, and (iii) minimizes the downstream impacts of the process waste streams on the environment.

During the past quarter, the project work plan and all associated technical/management reports were successfully completed (Subtask 1.1 - Work Plan Development). In addition, three coal samples have been selected for use in the proposed test program based on input provided by the industrial project participants (Subtask 2.1 - Coal Selection). Formal requests to ship the coal samples to the testing facility have also been made (Subtask 2.2 - Coal Procurement). Steps have also been undertaken to prepare the coal receiving areas for crushing, sizing and storing of the procured coals (Subtask 2.3 - Preparation and Storage). Work is now under way to complete the coal acquisition and sample preparation activities and to initiate the proposed trace element characterization studies (Task 3 - Characterization) and bench-scale test work (Task 4 - BenchScale Testing).
\end{abstract}

\title{
BACKGROUND
}

Coal preparation is widely regarded a cost-effective method for reducing the amounts of potentially hazardous air pollutant precursors (HAPPs) which occur as trace elements in run-ofmine coals. Unfortunately, many existing coal preparation plants are inefficient in removing trace elements because of poor circuit design and inadequate liberation of coal and mineral matter. These shortcomings are often difficult to correct in the absence of characterization data regarding the mineralogical association and washability of trace elements in run-of-mine coals.

In the present work, detailed trace element characterization studies will be conducted using samples from three different coal producing regions in the U.S. Using the characterization data, size classes, density fractions, etc., will be identified that are capable of meeting the desired trace element cleanup levels using low-cost conventional technologies such as heavy media bath, cyclones, spirals, etc. Composite (middling) particles which do not meet this criteria will be pulverized to improve liberation and subjected to a second series of characterization studies. This information will be used to determine whether additional clean coal can be recovered from the middlings fractions. 
Based on input provided by the industrial participants, one of the three base coal samples will be selected and subjected to a series of bench-scale tests using a wide variety of advanced physical separation processes. Processes evaluated in the bench-scale study will include column flotation cells and enhanced centrifugal gravity separators. These processes are believed to have the highest overall probability of gaining industrial acceptance. Data obtained from the bench-scale tests will be used to design optimum circuit configurations for the removal of trace elements. The various types of fine coal processing technologies may be combined in series to achieve high rejections of trace elements without ultrafine grinding.

To further enhance the removal of trace elements, the clean coal products from the benchscale tests will be treated using complexing agents. These reagents are designed to combine with specific elements and increase their effective solubility range. This "polishing" step will allow for the incremental removal of organically bound or poorly liberated trace elements that cannot be rejected by physical cleaning. In addition, some of the waste streams from the bench-scale tests will be subjected to a variety of laboratory tests to formulate strategies for controlling the release of trace elements discarded into refuse impoundments. Finally, the data obtained from the characterization studies and bench-scale tests will be used to develop a conceptual design for a proof-of-concept (POC) plant which maximizes coal recovery and trace element rejection.

\section{PROJECT OBJECTIVES}

The primary objective of this project is to develop and evaluate an advanced coal cleaning circuit that is capable of removing hazardous air pollutant precursors from run-of-mine coals in an efficient and cost-effective manner. Specific objectives of Phase I activities are (i) to determine the types and relative amounts of trace elements present in several eastern U.S. coals, (ii) to devise and test bench-scale circuits capable of maximizing the recovery of coal and the rejection of trace elements, (iii) to develop reliable performance data, operating guidelines and scale-up criteria for the proposed circuits, and (iv) to formulate strategies which minimize the downstream impact of trace elements on the effluent streams from the refuse impoundment.

\section{PROJECT TASKS}

\section{Task 1 - Project Planning}

\section{Subtask 1.1 - Work Plan Development}

A kick-off meeting was held with the DOE's Contracting Officer's Representative (COR) on November 17, 1995 at Virginia Tech to discuss the proposed characterization work and bench-scale testing programs. Input gathered during this meeting was used to prepare a draft project work plan which was submitted to DOE on November 24, 1995. This document provided a detailed description of the test programs, experimental procedures, analytical methods, and reporting guidelines that would be utilized to ensure the successful completion of the proposed work. Drafts of several other 
technical/management project plans were also submitted at this time. Specific documents provided with the project work plan included:

- Work Breakdown Structure (WBS)

- Project Team Assignments

- Detailed Project Schedule

- Project Reporting Schedule

- Hazardous Substance Plan

- Project Management Plan

- Project Labor Plan

- Project Cost Plan

These documents were reviewed by the COR and several minor modifications were requested. After discussions with the project subcontractors, the draft project work plan was modified and the revised project work plan was resubmitted to DOE on January 19, 1996 for final approval.

\section{Subtask 1.2 - Project Reporting}

A reporting requirements schedule was prepared by VPI\&SU and provided to each of the primary subcontractors. As a result of this planning, all project reports required to date have been submitted in a timely fashion to DOE. These include all status, management and technical reports. Furthermore, no delays are currently anticipated in meeting any future reporting requirements.

\section{Task 2 - Sample Acquisition}

\section{Subtask 2.1 - Coal Selection}

The project work plan specifies that three different coal samples from major bituminous coal producing regions in the Northern Appalachia, Central Appalachia and the Illinois coal basins be selected for the proposed test work. Table 1 provides a summary of the coals seams that have been selected. The selections were largely based on input provided by the industrial participants, i.e., Consol and EPRI.

Table 1 - Coal samples selected for characterization and testing.

\begin{tabular}{cccc}
\hline Sample & Coal Seam & Supplier & Request \\
\hline 1 & Pittsburgh No. 8 & Consol Inc. & 5 tons \\
2 & Illinois No. 6 & EPRI (Illinois Power) & $1000 \mathrm{lbs}$ \\
3 & Pocahontas No. 3 & Consol Inc. & $1000 \mathrm{lbs}$ \\
\hline
\end{tabular}


Both the Pittsburgh No. 8 and Illinois No. 6 seams are well known for their large reserve base and relatively high pyritic sulfur content. These coals are believed to be representative of coals from mines processing high-to-moderate sulfur coals. The third coal, i.e., Pocahontas No. 3, was selected to represent the high-quality, low-sulfur coal regions of southwestern Virginia and southern West Virginia.

\section{Subtask 2.2 - Coal Procurement}

Preliminary calculations were made to estimate the mass of coal required to successfully complete the proposed test work. Figure 1 shows the estimated weight splits for the coal characterization work. The weight fractions obtained by screening were estimated from the RosinRammler distribution using sizing parameters typical of eastern coals. According to this estimation procedure, approximately $40 \%$ of the run-of-mine feed coal is expected to be coarser than $10 \mathrm{~mm}$. When crushed to below $10 \mathrm{~mm}, 70 \%$ of the coal is assumed to be contained in the $10 \mathrm{~mm} \times 20$ mesh fraction, $20 \%$ in the $28 \times 100$ mesh fraction, $7 \%$ in the $100 \times 270$ mesh fraction and $3 \%$ in the 270 mesh $\times 0$ fraction. The weight fractions obtained from the float-sink tests were estimated on the basis of washability data for a typical Pittsburgh seam coal (Cavallaro et al., "Sulfur and Ash Reduction Potential and Selected Chemical and Physical Properties of United States Coals, DOE/PETC/TR90/7, Vol. 1., Eastern Region, 1990). In this case, the weight splits for the float 1.3, 1.3 x 1.5, $1.5 \times$ $1.7,1.7 \times 1.9$ and sink 1.9 specific gravity fractions have been assumed to correspond to weight fractions of $40 \%, 20 \%, 10 \%, 10 \%$ and $20 \%$, respectively. The assumption that the same weight splits can be used throughout the characterization procedure and known to be incorrect. However, in the absence of reliable experimental data, this assumption has been deemed acceptable for providing gross estimates of the mass required to complete the characterization studies. The weight split calculations indicate that approximately $250 \mathrm{~kg}(550 \mathrm{lbs})$ of feed coal must be used in the characterization work. This amount of sample is necessary to maintain an adequate sample mass (i.e., $>10 \mathrm{~kg}$ ) during the float-sink testing of the recrushed middlings. All other estimated weights exceed the minimum value required to obtain representative samples.

Similar estimates of the mass of coal required to complete the proposed bench-scale test work are summarized in Figure 2. The same particle size and specific gravity splits were used in the estimation procedure. According to these calculations, a minimum of approximately $3,000 \mathrm{~kg}$ of feed coal will be necessary to generate the $250 \mathrm{~kg}$ sample required for the enhanced gravity separator (EGS) studies to be conducted at Virginia Tech and Southern Illinois University.

In light of the estimated weight splits, Consol Inc. was requested to provide approximately 5 tons of the Pittsburgh No. 8 seam coal for use in the characterization studies and bench-scale testing program. Likewise, the Electric Power Research Institute (EPRI) was requested to provide approximately $1000 \mathrm{lbs}$ of Illinois No. 6 seam coal from Illinois Power. Each of these industrial participants assumed the responsibility for the sampling campaign and safe transportation of the selected coal samples to VPI\&SU. Both Consol and EPRI have agree to provide these services in accordance with their cost-sharing commitments. Existing funding commitments are only adequate to permit the proposed test work to be completed in its entirety 
Figure 1

ESTIMATED WEIGHT SPLITS FOR CHARACTERIZATION TEST WORK

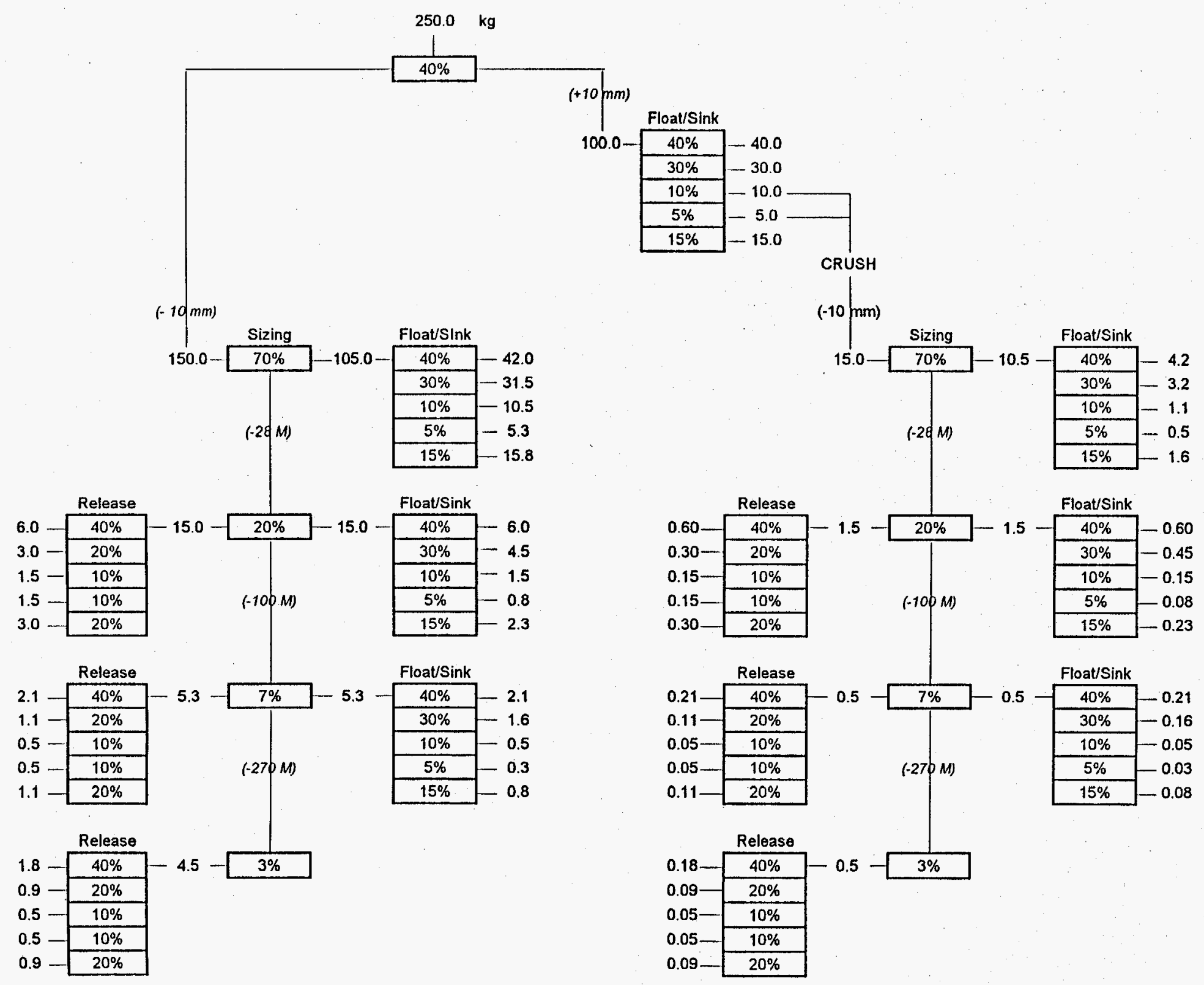


Figure 2

ESTIMATED WEIGHT SPLITS FOR CHARACTERIZATION TEST WORK

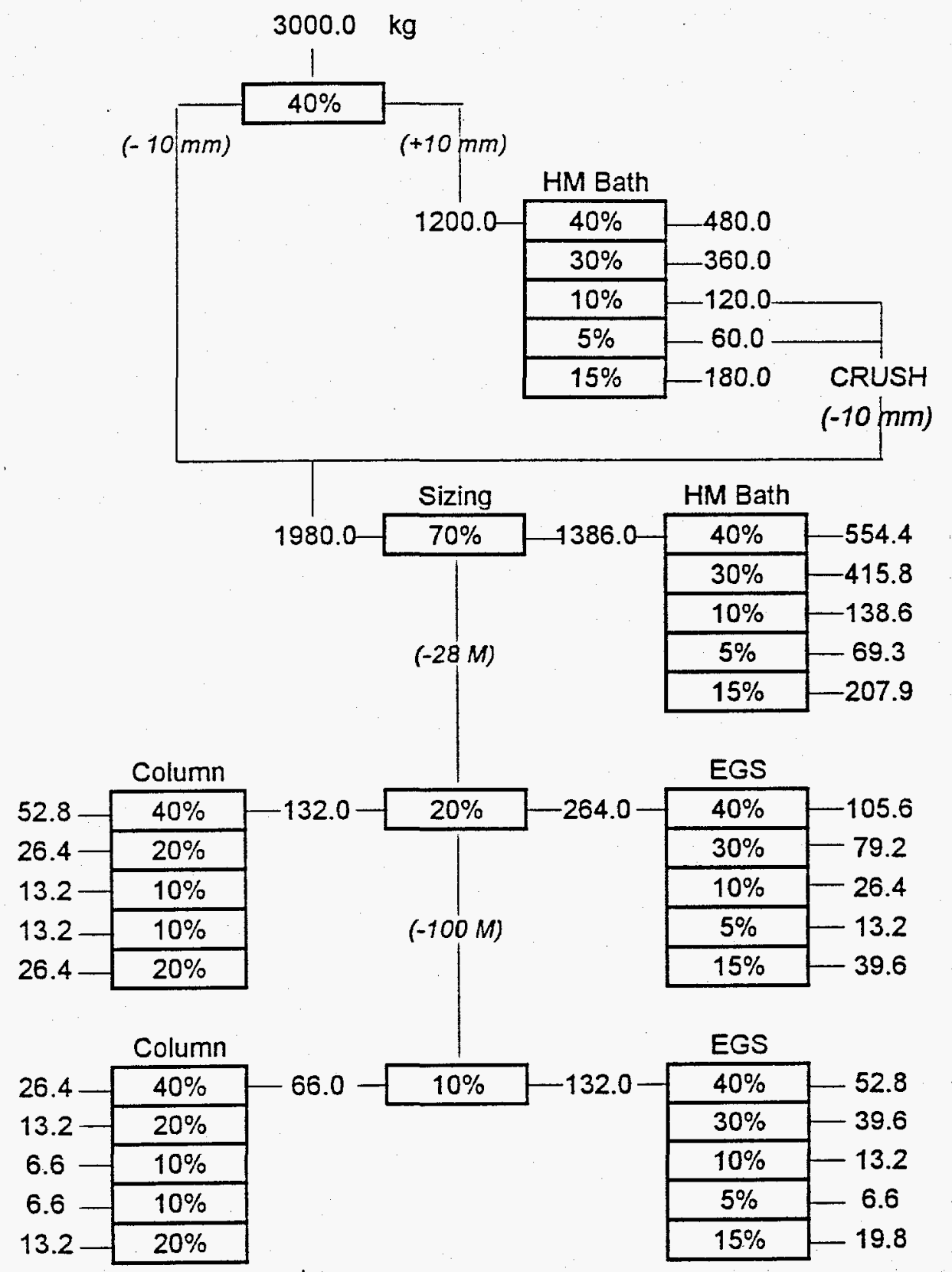


with the Pittsburgh No. 8 and Illinois No. 6 coals. Therefore, the third coal sample, i.e, Pocahontas No. 3, has not yet been requested pending notification of full project funding by DOE. This situation will be discussed in greater detail with the DOE COR.

\section{Subtask 2.3 - Preparation and Storage}

Appropriate areas have been cleared to receive the requested coal samples at the Coal Research and Design Facility at Virginia Tech. Approximately twenty 55-gallon drums have been procured for storing the samples used in the characterization studies. These drums have been lined with plastic inserts to minimize inadvertent contamination of the coal samples. Arrangements have also been made to set up the crushing and/or screening equipment that will be required to generate the specified particle size fractions. The following size fractions will be prepared: $50 \times 10 \mathrm{~mm}, 10 \mathrm{~mm} \times 28 \mathrm{mesh}, 28 \times 100$ mesh, 100×270 mesh and $270 \mathrm{mesh} \times 0$. Each size fraction will be appropriately tagged and stored until needed in the characterization studies.

\section{SUMMARY, STATUS AND PLANNED WORK}

The project work plan and all associated technical/management reports were successfully completed during the past quarter (Subtask 1.1 - Work Plan Development). In accordance with Subtask 2.1 (Coal Selection), three coal samples have been selected for use in the proposed test programs. These coals were selected on the basis of input provided by the industrial project participants. Formal requests to ship the coal samples to the testing facility have been made. (Subtask 2.2 - Coal Procurement). The receiving areas for crushing, sizing and storing the procured coals is now underway (Subtask 2.3 - Preparation and Storage). It is anticipated that the coal acquisition and sample preparation activities will be completed during the next few weeks. The proposed trace element characterization studies described under Task 3 (Characterization) and the proposed bench-scale test work described under Task 4 (Bench-Scale Testing) should be well under way before the next technical progress report is submitted.

\section{DISCLAIMER}

\footnotetext{
This report was prepared as an account of work sponsored by an agency of the United States Government. Neither the United States Government nor any agency thereof, nor any of their employees, makes any warranty, express or implied, or assumes any legal liability or responsibility for the accuracy, completeness, or usefulness of any information, apparatus, product, or process disclosed, or represents that its use would not infringe privately owned rights. Reference herein to any specific commercial product, process, or service by trade name, trademark, manufacturer, or otherwise does not necessarily constitute or imply its endorsement, recommendation, or favoring by the United States Government or any agency thereof. The views and opinions of authors expressed herein do not necessarily state or reflect those of the United States Government or any agency thereof.
} 